\title{
Student Teachers's Readiness to Face Society 5.0 Challenges: Are They Ready to Teach with Competencies Needed?
}

\author{
Rinaldo Adi Pratama \\ History Education Department \\ Lampung University \\ Lampung, Indonesia \\ rinaldo@fkip.unila.ac.id \\ Muhammad Adi Saputra \\ History Teacher \\ SMAN 8 Tangerang \\ Tangerang, Indonesia \\ madisaputtra25@gmail.com
}

\author{
Inne Marthyane Pratiwi \\ PGMI Department \\ UIN Sunan Gunung Djati \\ Bandung, Indonesia \\ inne.mp@uinsgd.ac.id
}

\author{
Nur Indah Lestari \\ History Education Department \\ Lampung University \\ Lampung, Indonesia \\ nur.indahlestari@unila.ac.id
}

\begin{abstract}
Society 5.0 has a consequence on all aspects including the education aspect. Education is required to be able to adapt to any changes that exist, of course, in this case, the society 5.0 era has an impact on the readiness for the job of student teachers to prepare for the changes. This study aims to examine the readiness of student teachers in facing the challenges that will be faced with the implementation of Society 5.0 and the competencies needed in the future. This study uses a descriptive quantitative approach with a survey method. The sample from two teacher training and education colleges $(n=305)$ was surveyed to explore the extent to which students felt prepared for the job with society's 5.0 challenges. Collecting data uses a questionnaire and data analysis using descriptive statistics. This study describes four competencies namely communication skills, leadership, curiosity, and comprehension reading skill. Overall, the results identified that student teachers are quite ready for leadership and comprehension reading skills and need to be developed for communication and curiosity skills among these student teachers. These four competencies become important to be researched because they must be owned by every student teacher and affect the important role of teacher training and college education institution in shaping their professional competencies.
\end{abstract}

Keywords-teacher competencies, society 5.0, studentteacher, readiness for the job

\section{INTRODUCTION}

Some time back the term Industrial Revolution 4.0 decorated many news and scientific works from various scientific groups. Industrial Revolution 4.0 makes all lifelines must be prepared to prepare the competencies needed in the era of disruption [1]. However, while the Industrial Revolution 4.0 was still a discussion in almost all countries including Indonesia, Japan at the end of 2019 introduced a new idea called Society 5.0, and of course, this could have an impact on the education sector, especially in the preparation of professional teachers who are ready with all challenges in the era of society 5.0 [2].

Until now, Indonesia is based on the framework outlined in Making Indonesia 4.0 as one of the strategies to face the challenges of the Industrial Revolution 4.0 by improving the quality of Human Resources [3], but there is still no formulation of how to prepare human resources to face the demands of society 5.0. The presence of the society 5.0 era is certainly a big challenge for prospective teachers in Indonesia and Teacher Training Institution in Indonesia.

The existence of this era certainly presents technological advances, especially in the field of education [4]. In the era of society 5.0, the world of education is required to follow the development of technology that is developing rapidly and utilize information and communication technology as a more advanced and advanced facility to facilitate the learning process. In addition, it is expected that with the use of information technology and communication the learning mindset can shift from teacher-centered to student-centered. In the era of society 5.0 teachers are required to be able to use various technologies in all sectors of life. This urgency is reinforced by the fact that all today's learners are millennials inseparable from the use of smart technology in their lives [5]. 
Quality education will not be done without professional teachers, because teachers have a central role in education. Teachers have the task to design learning, shape the character of learners, and optimize the talents and potential of learners to form quality human resources [6]. Therefore, in the current era, prospective teachers must have competencies that are following future expectations and objectives because teachers will still be needed to shape the character of the nation's children with ethics, tolerance, and good values [7].

Based on the Regulation of the Minister of National Education of the Republic of Indonesia Number 16 of 2007 concerning Teacher Qualification and Competency Standards, four competencies must be possessed by a teacher [8]. These competencies include pedagogy competencies, personality competencies, social competencies, and professional competencies. However, along with the idea of society 5.0 , teachers are also required to have competencies that are following the development of the times. To face the era of society 5.0, there are at least four additional competencies that must be possessed by prospective teachers, namely communication competence, leadership and endurance competence, curiosity competence, and comprehension reading skills. This is following the statement of the Minister of Education of Japan, Yoshima Hayashi has considered how to adjust the education that is better for each of his students in Japan to face society 5.0. [9].

The four additional competencies required by prospective teachers above will certainly be able to make a real contribution to improving the quality of human resources as stated in Making Indonesia 4.0 by the Indonesian government [3].

Before addressing the meaning of teacher competence, we must first establish the meaning of competence. Competence is a term used widely by different people in different contexts; therefore, it is defined in different ways. Teacher education and job performance are two contexts in which the term is used. Competency is a collection of knowledge, behaviors, and skills that teachers must have to achieve learning and educational goals. Competencies are obtained through education, training, and selflearning by utilizing learning resources [8].

We often hear about the abilities that learners must-have in the 21 st century. So, what about the skills that teachers should have in this era? What instructional skills do teachers need in society 5.0 to prepare for quality education? How do they have skills that differ from the skills teachers have needed in the past?

In recent years, the output of higher education has changed significantly [9]. If previously, the main goal of Teacher Training Institution was that it approves students with certain types of knowledge that they are expected to apply later, the university is currently focusing primarily on life skills.

Culturally competent, talented, innovative, and creative professional problem solver, skilled and critical thinker, and of course needed by all prospective teachers [10] [11]. Prospective teachers must be able to adjust to being able to provide critical thinking learning opportunities for students. Teachers should give students skills that will help them work collaboratively in teams, become decision-makers, plan and manage their time effectively, listen to each other and choose the right communication strategy at the right time [12] [13]. As such, we have understood that, to meet these new teaching requirements, we need the skills to answer society's 5.0 challenges.

A big challenge for prospective teachers in addition to having to develop critical ways of thinking must also be able to act as a facilitator for students to provide direction in finding solutions. When society 5.0 has been echoed in various parts of the world, currently teachers and students of prospective teachers are not considered to have readiness in facing this new era. Research related to teacher competency readiness has been tried by Mohamed, Valcke \& Wever the results show that to face the future demands of the main thing that must be developed on prospective teachers before they are ready to work is to form a professional competency [14]. In addition, Pangestu \& Nuraini's research results provide an idea that prospective primary school teachers are still lacking in the mastery of skills in the competence of commercialization of technology, competence in globalization, and competence in future strategies in the face of the Industrial Revolution 4.0. [15]

Sunan Gunung Djati State Islamic University Bandung and Lampung University are universities that have a teaching faculty of teachers. Based on the above exposure, Society 5.0 has a tremendous impact on the world of Education and requires teachers to adapt quickly with the development of this new era, as the current readiness of prospective education or prospective teachers is still questioned. This research focuses on the analysis of the readiness of prospective teachers in facing the challenges of the Society 5.0 era. Student readiness indicators in this study include communication competence, leadership and endurance competence, curiosity competence, and comprehension reading skills.

This research will be able to provide an overview to policymakers, in this case, is the Educational and Teacher Training Institution to develop classroom learning so that it focuses on the competencies that are demanded by Society 5.0, and no longer focuses on knowledge transfer which results in teacher candidates being unprepared with the changing times. 


\section{RESEARCH METHOD}

\section{A. Research Design}

This study uses a qualitative approach with a case study model type. A qualitative approach is a research method based on the philosophy of post-positivism. The philosophy of post-positivism is a philosophy used to examine the condition of natural objects, where a researcher becomes a key factor as an instrument, then the data collection techniques are carried out in combination, the data analysis is inductive, and the results of his research emphasize the meaning of generalizes. This research aims to find out the competence of prospective teachers in facing era society 5.0. This study used the case study method. The case study method is an exploration of a limited system of one or several cases through the collection of detailed and in-depth data.

\section{B. Research Subject}

This research was conducted at UIN Sunan Gunung Djati Bandung and Lampung University. The subjects in this study numbered 305 students consisting of students who had studied education and teaching and had carried out field experience practices.

\section{Data Collection Techniques}

The data is collected through questionnaire questionnaires distributed to respondents through Google Form. Questionnaires were distributed to 305 teacher students from two state universities there UIN Sunan Gunung Djati in Bandung and Lampung University. Prospective teachers fill out questionnaires according to their circumstances as prospective teachers in the face of the 5.0 community era. The questionnaire contains 40 statements consisting of four indicators with each indicator represented by 10 statements.

To validate the questionnaire, it is conducted with expert testing that includes a construction validity test conducted that includes layout, indicator formulation, and question items.

\section{Data Analysis Techniques}

The data analysis techniques used are descriptive statistics and qualitative analysis. Descriptive statistics are used to describe data obtained from responses provided by prospective teachers in the form of frequency distribution tables.

\section{RESULTS AND DISCUSSIONS}

\section{A. Result}

This research aims to find out the competence of prospective teachers in facing society's 5.0 era. The data was collected through questionnaires distributed by Google Form. Questionnaires were distributed to as many as 305 prospective students from two universities. The student fills out a questionnaire according to his/her circumstances. The questionnaire contains 40 statements consisting of four indicators with each represented by 10 statements. The following is a table of spread results.

TABLE I. RESUltS OF STUDENT TEACHERS' COMPETENCY FOR COMMUNICATION INDICATORS

\begin{tabular}{|l|c|c|c|}
\hline & $\mathbf{N}$ & $\mathbf{\%}$ & Average Percentage \\
\hline Strongly Agree & 57 & $18,69 \%$ & \\
\hline Agree & 115 & $37,7 \%$ & \\
\hline Disagree & 106 & $34,75 \%$ & \multirow{2}{*}{$30,57 \%$} \\
\hline $\begin{array}{l}\text { Strongly } \\
\text { Disagree }\end{array}$ & 27 & $8,85 \%$ & \\
\hline Total & 305 & $100 \%$ & \\
\hline
\end{tabular}

Table 1 showed nearly half of students agreed $(37.7 \%)$, strongly agreed $(18.69 \%)$, and disagreed $(34.75 \%)$ with statements relating to communication indicators. Meanwhile, a small percentage of students responded strongly to disagree (8.85\%) communication indicator. The average percentage of student answers for communication indicators is $30.57 \%$. This shows that almost half of students have the readiness to face the Society 5.0 era related to communication indicators.

TABLE II. RESUlTS OF STUDENT TEACHERS' COMPETENCY FOR LEADERSHIP AND ENDURANCE

\begin{tabular}{|l|c|c|c|}
\hline & $\mathbf{N}$ & $\mathbf{\%}$ & Average Percentage \\
\hline Strongly Agree & 76 & $24,92 \%$ & \\
\hline Agree & 140 & $45,9 \%$ & \\
\hline Disagree & 75 & $24,59 \%$ & \multirow{2}{*}{$33,54 \%$} \\
\cline { 1 - 2 } $\begin{array}{l}\text { Strongly } \\
\text { Disagree }\end{array}$ & 14 & $4,59 \%$ & \\
\hline Total & 305 & $100 \%$ & \\
\hline
\end{tabular}

Table 2 showed nearly half of students answered agreeing $(45.9 \%)$, strongly agreeing $(24.92 \%)$, and disagreeing $(24.59 \%)$ statements relating to leadership and endurance indicators. A small percentage of students responded strongly to disapproval $(4.59 \%)$ indicators relating to leadership and endurance. Meanwhile, when reviewed based on the average percentage of students' answers to leadership and endurance indicators, almost half $(33.54 \%)$ students have readiness about leadership and endurance indicators in the face of the Society 5.0 era.

TABLE III. RESUlTS OF STUDENT TEACHERS' COMPETENCY FOR CURIOSITY

\begin{tabular}{|l|c|c|c|}
\hline & $\mathbf{N}$ & $\mathbf{\%}$ & Average Percentage \\
\hline Strongly Agree & 40 & $13,05 \%$ & \\
\cline { 1 - 2 } Agree & 95 & $31,15 \%$ & \multirow{2}{*}{$31,36 \%$} \\
\cline { 1 - 2 } Disagree & 131 & $42,79 \%$ & \\
\hline Strongly Disagree & 39 & $12,85 \%$ & \\
\hline Total & 305 & $100 \%$ & \\
\hline
\end{tabular}

Table 3 shows almost half of the students answered disagree $(42.79 \%)$ and agree $(31.15 \%)$ with statements relating to the curiosity indicator. A small percentage of students strongly agree $(13.05 \%)$ and 
strongly disagree $(12.85 \%)$ statements relating to the curiosity indicator. Meanwhile, the average percentage of student answers for curiosity indicators was $31.36 \%$. Thus, almost half of students have the readiness to face the Era of Society 5.0 about curiosity indicators.

TABLE IV. RESUlTS OF STUDENT TEACHERS' COMPETENCY FOR COMPREHENSION AND READING

\begin{tabular}{|l|c|c|c|}
\hline & $\mathbf{N}$ & $\mathbf{\%}$ & Average Percentage \\
\hline Strongly Agree & 33 & $10,82 \%$ & \\
\hline Agree & 144 & $47,21 \%$ & \\
\hline Disagree & 107 & $35,08 \%$ & \multirow{2}{*}{$36,24 \%$} \\
\hline $\begin{array}{l}\text { Strongly } \\
\text { Disagree }\end{array}$ & 21 & $6,89 \%$ & \\
\hline Total & 305 & $100 \%$ & \\
\hline
\end{tabular}

Based on Table 4, it can be seen that almost half of students answered agree $(47.21 \%)$ and disagree $(35.08 \%)$ statements relating to the comprehension and reading indicators. Meanwhile, a small percentage of students responded strongly $(10.82 \%)$ and strongly disagree $(6.89 \%)$ statements relating to the comprehension and reading indicators. The average percentage of student answers for the comprehension and reading indicator is $36.24 \%$. This suggests that nearly half of students are ready for the society 5.0 era in the comprehension and reading indicators.

TABLE V. Total SCORE OF StUdent Teachers' COMPETENCY BY INDICATORS

\begin{tabular}{|l|c|c|}
\hline & Score & Category \\
\hline Communication & 69,06 & Fair \\
\hline Leadership and endurance & 72,57 & Fair \\
\hline Curiosity & 66,84 & Fair \\
\hline Comprehension and reading & 73,51 & Fair \\
\hline Average & 70,83 & Fair \\
\hline
\end{tabular}

Table 5 shows the results of the analysis of student competency scores of prospective teachers in the face of the society 5.0 era. Based on the analysis obtained the average competency of students of 70.83 is in the Fair category. The results show that students have a fair competency readiness of prospective teachers in the face of the society 5.0 era.

Furthermore, researchers analyzed the competency score of prospective teachers in the face of the society 5.0 era reviewed based on indicators. In the communication indicator, the average student score of 69.06 is in the category of sufficient. This means that students have sufficient readiness in terms of communication. This indicator relates to the communication skills of prospective teachers either directly or indirectly effectively and efficiently. In addition, communication is conducted through ITbased social media. Students are quite able to utilize social media by paying attention to spelling in communicating effectively and efficiently. Students can also communicate well with friends and older parents either through IT-based media or face-to-face as a provision to communicate with colleagues and parents of future students [16].

However, students are very less good at actively mastering Communication using English. Communication skills using English are actively important to have in facing challenges in this era of society 5.0. This competency becomes important because based on previous research teachers consider the value and child-rearing competencies, subject knowledge, pedagogy, and curriculum as well as selfevaluation and professional development very important [17].

The average student score on the leadership and endurance indicator of 72.57 is in the sufficient category. Thus, students have sufficient readiness in facing the era of society 5.0 reviewed from their competence as candidates related to leadership and endurance. Students have excellent discipline demonstrated by compliance with applicable regulations in the campus, family, and community environment, including completing college assignments promptly.

Students can solve problems with a mature and thoughtful mind. Students are quite competent in managing classes and controlling the focus of learning. Students are quite active in activities that involve collaboration with others, both on and off-campus. Students have a limited network of friendships that make it difficult to actualize themselves. Some students feel that with the rapid development of technology, the role of teachers will be replaced. Guasch et. al. tried to explain how university teacher competencies in virtual teaching are needed they highlight the need to take an integrative look at the diverse roles/functions of teachers when designing training proposals for competency development. This need is just as important when training actions focus on a single competency, as is our focus on collaborative activity design, so that reconceptualization of teacher functions is explicitly recognized in teacher training practice [18].

According to Table 5, the average student score on the curiosity indicator of 66.84 is in the sufficient category. Of the four indicators, curiosity is the lowest score. Curiosity is a curiosity that arises and is possessed by students of something that has not been explained or answered. The results of the analysis showed that when they found information that sounded foreign, students tried to find out using their gadgets. Students rarely attend off-campus seminars and activities to increase their knowledge and capabilities. Few students conduct scientific research activities related to education and learning. Students prefer to play games rather than read the information in their spare time. Students have no interest in creating content or trying innovative novelty related to applications in an electronic device. 
Furthermore, on the indicator comprehension and reading the average student score of 73.51 is in the category of sufficient. In the course, students use electronic journals as a reference in the completion of lecture assignments. However, students copy the information regardless of a valid source. In addition to electronic journals, students use textbooks more as learning materials. Students do not take the time to download and read the latest articles every week to adjust to the times when the information in the article is newer than the information from the book. Students are sufficient to master the learning materials so that the level of truth and accuracy of the learning substance are discussed following the expected competencies in the 5.0 era. In addition, students are quite good at IT-based learning media.

Of the four competencies that should be possessed by prospective teachers from teacher training universities apparently, students are still weak in terms of curiosity skills which competencies are needed in the future to sustain such a large knowledge and flow of information. Students of prospective teachers must be able to improve their curiosity skills to be able to compete with people in the future. Aji stated that 21stcentury skills are needed to create individuals who can compete in this century. One of the important attitudes of 21 st-century competence is curiosity. Curiosity can help someone solve the problems they face. To improve and foster students' curiosity [19].

\section{B. Discussion}

Based on the results of the study, the average competency score of prospective teacher students in facing the era of society 5.0 is 70.83 which was in the sufficient category. Competence is essential for students to pursue excellence as an educator. The central figure in the educational process is the teacher [20]. Teachers need a wide range of competencies to face the challenges of today's complex world. Competence is defined as the knowledge, skills, and attitudes needed to be competitive in the era of society 5.0. Preparation of student-teacher candidates and professional development must be prepared carefully, not only competence in teaching. The competencies in question consist of communication, leadership, and endurance, curiosity, reading, and comprehension

In the communication indicator, the average score of 69.06 is in the category of sufficient. Student communication is not only direct but can be done using IT-based media. Students need to master technical skills, know when and how to use current educational technology, as well as the most appropriate type and level of technology to maximize student learning. Students are very less able to master communication using English actively. Communication skills using English are needed for students' future careers. This is in line with the results of previous research that showed that students are not ready for the era of society 5.0 in terms of English proficiency due to the absence of intrinsic motivation to learn the language, student awareness of the needs of English competence is not in line with the desire to meet these needs [21], [22].

A teacher needs to have leadership and endurance competencies. The results showed prospective teacher students had a leadership and endurance score of 72.57 with sufficient categories. Effective teachers are effective leaders, and effective leaders are great teachers or seen from indicators of student growth [23]. This means that great teachers have great leadership skills and great leaders are effective teachers [20]. One attitude that shows that students have good leadership and endurance is the discipline shown by adherence to the rules. Research shows that students are quite active in activities that involve collaboration with others. This is in line with the standard ability of professionalism of a teacher that teachers need to collaborate and communicate effectively with family, co-workers, and the community.

Of the four indicators, curiosity has the lowest score of 66.84 with enough categories. Students rarely attend webinars and off-campus activities to increase their knowledge and capabilities. Only a few students conduct scientific research activities related to education and learning. Students prefer to play games rather than read the information in their free time. Students have no interest in creating content or trying innovative new things related to applications in an electronic device. The younger generation is reliable in operating technology but less careful in mastering technology [24]. The younger generation tends to operate technology just for fun. On the other hand, students try to find out using their devices when they find information that sounds foreign so as not to be easily exposed to hoaxes. This is inversely proportional to the results of a study conducted by Kovacs which states that students easily spread viral information without verifying the truth first. Lee and Talwar [25] argue that hoax information is difficult to avoid in everyday life because within 10 minutes of conversation the average person commits 3 lies. Therefore, improving digital literacy skills is important so that students master the processing of information in the media so that although the thinking bias is human nature, students are expected to still be able to think rationally by not easily follow the flow of information that is not necessarily valid.

Comprehension and reading indicators scored highest in the study. This is indicated by students enough to master the learning material so that the level of truth and accuracy of the learning substance is discussed following the competencies expected in era 5.0. In addition, prospective students are quite masters of IT-based learning media. This is following the results of Lubis's research [26] that the association that houses teachers is very important in developing 
teacher competence, especially in developing technology-based learning or e-learning. However, on the other hand, students do not take the time to download and read the latest articles every week to adjust to the times. In line with research conducted by Rahman, Ariawan, \& Pratiwi [27] which showed that students are less interested in reading articles even though the information on the article is more recent than information from books. Though this is needed so that students can add the latest knowledge and improve their competence as prospective teachers.

With the challenges of the society 5.0 era, the Teacher Training Institution must play an important role in preparing prospective students to enter the tougher job competition. Not only adjusting the curriculum and training educators but teaching soft skills that play a role in the era of society 5.0 is also a must. Although machines can perform many repetitive tasks better than humans, humans are more skilled in creative activity, creativity, critical thinking, social interaction, and physical abilities [21]. Therefore, Teacher Training Institution must develop student competencies so that its graduates can work with machines effectively and efficiently side by side rather than competing with them.

The results of this study are limited and only apply to study participants so they cannot be generalized in a broader context. Era society 5.0 is a relatively new issue in the education sector in Indonesia context, especially regarding the readiness of teachers and prospective students in facing this era. Thus, further studies are needed on this topic with a more significant number of participants from various regions in Indonesia. In addition, further research is needed that aims to identify things that can be done by various parties, especially Teacher Training Institution to encourage the competence of prospective teacher students in facing the era of society 5.0.

\section{CONCLUSION}

Based on the results of the research above shows that student teachers are not ready in facing the challenges that will be faced in the era of society 5.0. It appears that out of the four indicators all showed in enough categories with an average value of 70.83. The highest score of the four competencies studied was comprehension and reading with a total score of 73.51 while the lowest was curiosity competence with a score of 66.84. This indicates that the Teacher Training Institute should pay more attention to be able to increase the curiosity of prospective teachers to compete in a world that demands such abilities.

\section{REFERENCES}

1] T. Teo, S. Unwin, R. Scherer and V. Gardiner, "Initial teacher training for twenty-first century skills in the Fourth Industrial Revolution (IR 4.0): A scoping review," Computers \& Education, vol. 4, no. May, 2021.
[2] T. Salimova, N. Guskova, I. Krakovskaya and E. Sirota, "From industry 4.0 to Society 5.0: Challenges for sustainable competitiveness of Russian industry," OP Conference Series: Materials Science and Engineering, vol. 497, no. 1, 2019.

[3] A. Hidayatno, A. R. Destyanto and C. A. Hulu, "Industry 4.0 technology implementation impact to industrial sustainable energy in Indonesia: A model conceptualization," Energy Procedia, vol. 156, no. -, pp. 227-233, 2019.

[4] K. Fukuda, "Science, technology and innovation ecosystem transformation toward society 5.0," International journal of production economics, vol. 220, no. 1, 2020.

[5] N. P. Y. Parwati and I. N. B. Pramartha, "Strategi Guru Sejarah Dalam Menghadapi Tantangan Pendidikan Indonesia Di Era Society 5.0," Widyadari: Jurnal Pendidikan, vol. 22, no. 1, pp. 143-158, 2021

[6] F. L. Pigge, "Teacher competencies: Need, proficiency, and where proficiency was developed," ournal of Teacher Education, vol. 29, no. 4, pp. 70-76, 1978.

[7] H. Jan, "eacher of 21st century: Characteristics and development," Research on Humanities and Social sciences, vol. 7, no. 9, pp. 50-54, 2017.

[8] Regulation of the Minister of National Education, Regulation of the Minister of National Education about Teacher Qualification and Competency Standards, 2007.

[9] Global Japan, "How Japan is Preparing its Students for Society 5.0.," [Online]. Available: https://foreignpolicy.com/sponsored/how-japan-is-preparingits-students-for-society-5-0/.

[10] S. Öngören, "Investigation of Prospective Preschool Teachers' Digital Literacy and Teacher Readiness Levels," International Journal of Modern Education Studies, vol. 5, no. 1, pp. 181204, 2021.

[11] M. Voet and B. D. Wever., "Preparing pre-service history teachers for organizing inquiry-based learning: The effects of an introductory training program," eaching and Teacher Education, vol. 63, pp. 206-217, 2017.

[12] M. Haigh, F. Ell and V. Mackisack, "Judging teacher candidates' readiness to teach," Teaching and Teacher Education, vol. 34, pp. 1-11, 2013.

[13] S. K. Howard, J. Tondeur, J. Ma and J. Yang, "What to teach? Strategies for developing digital competency in preservice teacher training," Computers \& Education, vol. $165,2021$.

[14] Z. Mohamed, M. Valcke and B. D. Wever., "Are they ready to teach? Student teachers' readiness for the job with reference to teacher competence frameworks," Journal of Education for Teaching, vol. 43, no. 2, pp. 151-170, 2017.

[15] K. Pangestu and N. L. S. Nuraini, "Kesiapan Calon Guru Sekolah Dasar Dalam Menghadapi Era Revolusi Industri," Elementary School Journal PGSD FIP UNIMED, vol. 10, no. 2 , pp. 40-47, 2020.

[16] C. P. Bhakti and I. Maryani, "Peran LPTK dalam Pengembangan Kompetensi Pedagogik Calon Guru," Jurnal Pendidikan: Teori dan Praktik, vol. 1, no. 2, pp. 98-106, 2017.

[17] N. Pantić and T. Wubbels, "eacher competencies as a basis for teacher education-Views of Serbian teachers and teacher educators," Teaching and teacher education, vol. 26, no. 3, pp. 694-703, 2010

[18] T. Guasch, I. Alvarez and A. Espasa, "University teacher competencies in a virtual teaching/learning environment: Analysis of a teacher training experience," eaching and Teacher Education, vol. 26, no. 2, pp. 199-206, 2010. 
[19] S. H. Aji, "Implementation of Android-Based Physics Learning Media in Increasing High School Students' Curiosity.," 6th International Seminar on Science Education (ISSE 2020), pp. 358-366, 2021.

[20] E. Block, F. Crochet, L. Jones and T. Papa, "The Importance of Teacher's Effectiveness," Scientific Research, vol. 3, no. Special Issue, pp. 1164-1172, 2012.

[21] R. Yosintha, "Indonesian Students' Atitude towards EFL Learningin Respnse to Industry 5.0," Metathesis: Journal od English Language Literature and Teaching, vol. 4, no. 2, pp. 163-177, 2020.

[22] E. Burgos and S. Perez, "Hilean 12th Graders' Atitudes towards English as a Foreign Language," Colombian Applied Linguistics Journal, vol. 17, no. 2, pp. 313-324, 2015.

[23] T. Whitaker, "Setting the Tone leadership," Association of California School Administrators, vol. 33, pp. 20-22, 2004.

[24] Blummer, "Digital Literacy Practices Among Youth Populations: A Review of The Literature," Education Libraries: Childrens Resources, vol. 31, no. 3, pp. 38-45, 2008.

[25] K. Lee and V. Talwar, Children and Lying: A Century of Scientific Research, Blackwell, 2014.

[26] S. Lubis, "Peningkatan Profesionalisme Guru PAI Melalui Kelompok Kerja Guru (KKG)," Jurnal Pendidikan Agama Islam Al-Thariqah, vol. 2, no. 2, pp. 189-205, 2017.

[27] Rahman, V. A. N. Ariawan and I. M. Pratiwi, "Digital Literacy Abilities of Students in Distance Learning," Advances in SOcial Science, Education and Humanities Research, vol. 509, pp. 592-598, 2020. 